\title{
Effects of Teacher's Corrective Feedback on Accuracy in the Oral English of English-Majors College Students
}

\author{
Ruili Chu \\ Foreign language college of Tianjin polytechnic university, Tianjin, China \\ Email: trinatrina@163.com
}

\begin{abstract}
In current English major college teaching in China, there is a common phenomenon that although many students have learned a great deal of grammatical knowledge and vocabulary, most of them are still unable to speak English accurately. The teaching method is has changed from focus on the grammar structure of language to task-based teaching or communicative teaching. However, these two methods, fluency of language is the main goal of teaching while accuracy is often overlooked. In recent years, corrective feedback, due to its potential role in facilitating oral English development, has become a hot research topic in second language acquisition abroad. Teachers' corrective feedback is an indispensable part in foreign language teaching. With the occurrence of the theories of "Input Hypothesis" " interaction Hypothesis" and "Noticing Hypothesis", researchers have carried out studies on corrective feedback from various perspectives. This paper tries to solve the following questions: 1 . Whether corrective feedback have a positive effect on improving oral English accuracy? 2. Two types of corrective feedback, which types have a better effect on English accuracy? 3. If corrective can improve oral English accuracy, but for the highlmedium and low group of students, does it have the same improving effectiveness?
\end{abstract}

Index Terms - corrective feedback, oral accuracy, teaching method

\section{INTRODUCTION}

So far, there are some problems in researches on oral production. First, most of researches focus on fluency, whereas accuracy and complexity are considered as one aspect of fluency to be examined. Secondly, at recent, communicative teaching method and task-based teaching method are very popular and accepted by most researchers and teachers. But, these two teaching method also take on some limitations. The most problem is that these two methods overemphasize the importance of fluency while overlook the accuracy.

Second language acquisition (SLA) researchers' opinions on the effectiveness of corrective feedback are different. One group holds that corrective feedback is necessary (White, 1989, 1991) because it can match the learners' utterance with its corresponding version in the target language and draw the learners' attention to structures that have not been mastered, thus initiating a learning process; while another group maintains that changes in the learner's primary linguistic data, not by corrective feedback and some researchers even advocate to abandon the corrective feedback in classroom interaction due to its limitations(e.g. Truscott, 1999).A number of studies have examined whether corrective feedback in a communicative oral task-based language classroom is effective (e.g., Doughty \& Varela, 1998; Long, Inagaki \& Ortega, 1998; White, 1991;Tomasello and Herron, 1988, 1989; Lightbown\&Spada,1990; Bohannon \& Stanowics, 1988; Demetras, Post, \& Snow, 1986; Farrar, 1992; Saxton, 1997).

Corrective feedback has a positive effect on oral accuracy. The present study is a kind of classroom-oriented research, which the main purpose is to investigate the effect of corrective feedback on oral accuracy development.

\section{IMPORTANT TERMS IN THIS PAPER}

\section{A. Corrective Feedback}

The definition of corrective feedback. It is necessary to state that errors are a natural part of the learning process (Tornberg, 2005). Errors are common characteristic of language acquisition and learning. That is to say everyone will make errors in the process of learning no matter learning the first language or the second language. However, in second language classroom, teacher usually wants students to speak as much as possible and encourage them to speak with the purpose of improving communication competence. When students speak SL they will also make various errors, and if these errors are not corrected, students will mistake them for correct form and internalize them to their interlanguage system. So, the oral English will be easy to fossilize if teacher do not provide corrective feedback.

Lightbown and Spada (1999) give corrective feedback definition such as: Any indication to the learners that their use of the target language is incorrect. The learners receive various responses. For example, When a language learner says, 'He go to school everyday', corrective feedback can be explicit, for example, 'no, you should say goes, not go' or 
implicit 'yes he goes to school every day', and may or may not include metalinguistic information, for example, 'Don't forget to make the verb agree with the subject'. (p.171-172). In the following part will introduce six types of corrective feedback with examples.

Day, et al. (1984) employ corrective feedback to refer to the native speakers' response to what they perceived to be errors committed by non-native speakers. The definition has its limitations, the provider of corrective feedback only non-native speakers, in fact it includes all the people, native-speaker or non- native speaker.

Corrective feedback does not just emphasize the form of language just like the traditional teaching method; it draws students' attention to linguistic forms as they arise incidentally in lessons whose overriding focus is on meaning or communication.

The classification of corrective feedback. When studying corrective feedback and learner uptake in four French immersion classrooms at the primary level, Lyster \& Ranta (1997) put forward six types of corrective feedback. The six types are: 1) explicit correction: teachers supply the correct form and clearly indicate that what the students say is incorrect; 2) recast: teacher implicitly reformulates all or part of the student's Utterance; 3) elicitation: teacher directly elicits a asking questions or by pausing to allow students to complete teacher's utterance, or asking students to reformulate their utterance; 4) metalinguistic feedback: to the well-formedness of the student's utterance; 5) clarification request: teacher's request for further information from a student about a previous utterance; 6) repetition: teacher repeats the student's ill-formed utterance, adjusting intonation to highlight the error.

TABLE. 1

EXAMPLES OF THE SIX TYPES OF CORRECTIVE FEEDBACK

\begin{tabular}{|l|l|}
\hline explicit correction & $\begin{array}{l}\text { St: he take the bus to go to school. } \\
\text { T; oh, you should say he takes. he takes the bus to go to school. }\end{array}$ \\
\hline recast & $\begin{array}{l}\text { St: he take the bus to go to school. } \\
\text { T:he takes the bus to go to school. }\end{array}$ \\
\hline elicitation & St: he take the bus to go to school. \\
& T: he ...? \\
& T: how do we form the third person singular form in English? \\
& T: can you correct that? \\
\hline metalinguistic feedback & St: he take the bus to go to school. \\
& T: do we say he take? \\
& T:How do we say when it forms the third person singular form? \\
\hline clarification request & St: he take the bus to go to school. \\
& T: parden me? \\
\hline repetition & St: he take the bus to go to school. \\
& T; he take? \\
\hline
\end{tabular}

According the six types of corrective feedback, the author comes up with two types of corrective feedback. The first one can facilitate peer- and self-repair (elicitation; metalinguistic feedback; clarification request; repetition); the second one just rephrase of learner output without push peer- or self- correct. (explicit correction; recast). In order to write the two types conveniently, the author give reader two terms to stand for them. The first type of corrective feed back can be abbreviated as type1; the second is type 2 .

Lyster and Ranta (1997) presented a study of classroom interaction and classified various types of corrective feedback used by teachers in response to learner errors. The percentage distribution of the six feedback types was: recasts 55\%; elicitation 14\%; clarification requests $11 \%$; metalinguistic clues $8 \%$; explicit correction $7 \%$; repetition of error 5\%. (cited from Lyster 1998a: 189). Obviously, most teachers like to use recast (55\%). But recasts led to the lowest rate of uptake-including the lowest rate of repair. What is more, both recasts and explicit correction can not lead to any peer-or self-repair in that they already provide correct forms to learners. Opposite to that, elicitation, metalinguistic clues, clarification request, and the repetition of error not only made higher rates of uptake but also can be able to elicit peer- and self-repair. The last four techniques are called negotiation of form. The negotiation of form can benefit second language learner in at least two ways: (1) by providing opportunities for learners to proceduralize target language knowledge already internalized in declarative form (cf. Hulstijn, 1990;Mclaughlin, 1990; Nobuyoshi \& Ellis, 1993; Towell, Awkins \& Bazergui,1996) and (b) by drawing learners' attention to form during communicative interaction in ways that allowed them to re-analyze and modify their non-target output as they tested new hypotheses about the target language (Pica, 1988; Swain, 1993,1995).

\section{B. Oral Accuracy}

Skehan (1996) state that accuracy refers to "how well the target language is produced in relation to the rule system of the target language". An analysis of target-like use can measure accuracy, considering both the contexts and uses of the structure in question (Pica, 1983). Accuracy; complexity and fluency are three important parts of oral speaking. Every teacher should keep balance of the three parts.

Accuracy is identified various types by researchers. Omaggio (1986) says that accuracy includes grammatical, sociolinguistic, semantic, rhetorical accuracy and some surface features just like spelling and punctuation and pronunciation. Because the purpose of the present study is to determine the development of oral production, only linguistic accuracy (including grammatical and syntactic accuracy) is examined in this thesis. 
Many accuracy indexes have been employed to measure oral language for different purposes.

TABLE. 2

INDEXES EMPLOYED IN THE MEASUREMENT OF ORAL LANGUAGE ACCURACY

\begin{tabular}{|l|l|l|}
\hline researchers & Year of study & Indexes employed \\
\hline Forster 、Skehan & 1996 & The percentage of error-free clauses to all clauses (EFC/C) \\
\hline Zhang and Wu & 2001 & The error- free T-unit per T-unit(EFT/T) \\
\hline Yuan and Ellis & 2003 & error- free clauses and correct verb forms \\
\hline Larsen-Freeman & 2006 & The proportion of T-unit \\
\hline Iwashita et al. & 2008 & Verb tense, third person singular, prepositions, articles use and ratio of error- free T-units \\
\hline Tavakoli ,Forster & 2008 & The ratio of error- free clauses(EFC/C) \\
\hline
\end{tabular}

Foster, Tohkyn \& Wigglesworth (2000) used "As-unit" to measure speech. "As-unit" consists of an independent clause or sub-clausal unit, together with any subordinate clauses) associate with either but it doesn't include repair as reformulation, replacement, repetition, false start and hesitation The following sentence has two As-units marked by“/../"They should have their own careers hand they can successfully depend on themselves::if they can make a living."

In this paper, some terms also need to calculate oral accuracy. "Correct As-unit” refers to As-unit without any errors. "Sub-unit" consists minimally of a finite of non-finite verb element plus at least one other clause element (Subject, Object, Complement and Adverbial) or it is amount to compound sentence in other term. "Incorrect sub-unit" includes sub-unit with any errors. "Total words" means all words except repair, repetition, hesitation, etc. "Total errors" consists of all errors of lexical, morphological, syntactical or textural. "Self-repair" refers to self -correction in speaking when the speakers are aware of the error and correct it by themselves. "Ratio of error free As-units" is an index to measure accuracy of As-unit. REFAS=error free As-units/ all the As-units. The higher, the more accurate the language is. "Number of errors per 100 words" is an index to measure accuracy of total words. REW =total errors* 100/total words. The fewer the number, the more accurate the speech is. "Ratio of error sub-units" is an index to measure accuracy, but it can show the relationship between accuracy and complexity. RESUB= Incorrect Sub-unit /all Sub-units. The higher it is, the less accurate the Sub-unit is. And so on.

\section{RESEARCH DESIGN}

\section{A. Participant}

Subjects are Second-year English majors who come from Binzhou College in Shandong province. Every one of them has learned English for 7 to 8 years. The participants were selected from three classes taught by the same English teacher. There is a control class and two experimental classes, each class choose three students as subjects. Class one as control class which tech students without any type of corrective feedback. Class two and class three are experimental classes which apply type1 and type 2 respectively. The three students divided high $\backslash$ mediumllow group according to their oral achievement. This study lasts about sixteen weeks.

\section{B. Processes}

This study employs a pre-test, a post-test, classroom observation and interview. The first week give students a pre-test, gave students one task--let them speak according to a series of pictures, and make record of their speaking, and change the record into text. From the second week to fifth week, experimental classes are provided corrective feedback and the control class give none corrective feedback. The last week organize post-text, the task is similar to task in the pre-text.

\section{Instructional Treatments}

The present study adapt Foster, Tohkyn \& Wigglesworth's (2000) "As-unit" (the Analysis of Speech Unit) to measure the record. The SPSS (Statistical Package for the Social Sciences) is used as a statistical analytical instrument. The statistical techniques employed for analysis are Descriptive Statistics, One-Way ANOVA Analysis, Paired-Samples T- test, Independent-Samples T test Analysis.

\section{RESULTS AND DISCUSSION}

At the beginning of the experiment, in order to identify the three groups' level of oral accuracy, a pre-text is prerequisite. The goal of the pre-test is determine whether the three groups have significant difference. 
TABLE 4.1

ONE WAY ANOVA ANALYSIS FOR THREE CLASS IN PRE-TEST

\begin{tabular}{|c|c|c|c|c|c|}
\hline & Sum of Squares & $\mathrm{df}$ & Mean Square & $\mathrm{F}$ & Sig. \\
\hline Between Groups & .000 & 2 & .000 & 1.467 & .303 \\
Within Groups & .001 & 6 & .000 & & \\
Total & .001 & 8 & & & \\
\hline
\end{tabular}

The descriptive statistics for the three groups, including one way ANOVA analysis for each group, is shown in table 1. The data from the pre-test demonstrated that the subjects no matter from experimental class or control class are at the same level with no significant difference. ( $\mathrm{F}=1.467, \mathrm{P}=.303>0.05)$. In other words, the scores get from pre-test or post-test are not influenced by individual difference, make sure that the score just be influenced by corrective feedback ,try best to reduce the uncontrollable elements.

TABLE 4.2

PAIRED-SAMPLES T TEST FOR EXPERIMENTAL CLASS

\begin{tabular}{|c|c|c|c|c|c|c|c|c|}
\hline & \multicolumn{5}{|c|}{ Paired Differences } & \multirow[b]{3}{*}{$\mathrm{t}$} & \multirow[b]{3}{*}{ df } & \multirow[b]{3}{*}{ Sig. (2-tailed) } \\
\hline & \multirow[b]{2}{*}{ Mean } & \multirow{2}{*}{$\begin{array}{c}\text { Std. } \\
\text { Deviation }\end{array}$} & \multirow[b]{2}{*}{ Std. Error Mean } & \multicolumn{2}{|c|}{$\begin{array}{c}95 \% \text { Confidence Interval of the } \\
\text { Difference }\end{array}$} & & & \\
\hline & & & & Lower & Upper & & & \\
\hline $\begin{array}{rr}\text { Pair } 1 & \begin{array}{l}\text { Pre-test - } \\
\text { post-test }\end{array}\end{array}$ & -1.872 & 2.618 & .382 & -2.641 & -1.104 & -4.903 & 46 & .000 \\
\hline
\end{tabular}

The paired-samples $\mathrm{T}$ test analysis revealed that the learners in experimental classes receiving corrective feedback improve significantly in their post-test for their performance on the accuracy of oral English $(\mathrm{t}=.000<0.05)$. The results proved the hypothesis that error correction during oral communicative activities seemed to have a significant overall effect on students' oral achievement or proficiency.

On the whole, the learners in experimental classes made great progress for long term development of their oral accuracy. That is to say, both type 1 and type 2 of corrective feedback are effective in facilitating learner 'oral accuracy. See table 4.2. Learners learn best when they generated a hypothesis and received immediate feedback. Since learners may cognitively make a comparison between their own deviant utterances and the correct target language utterances.

TABLE 4.3

PAIRED-SAMPLES T TEST FOR TWO EXPERIMENTAL CLASSES

\begin{tabular}{|c|c|c|c|c|c|c|c|c|c|}
\hline & & \multicolumn{5}{|c|}{ Paired Differences } & \multirow[b]{3}{*}{$\mathrm{t}$} & \multirow[b]{3}{*}{$\mathrm{df}$} & \multirow[b]{3}{*}{ Sig. (2-tailed) } \\
\hline & & \multirow[b]{2}{*}{ Mean } & \multirow{2}{*}{$\begin{array}{c}\text { Std. } \\
\text { Deviation }\end{array}$} & \multirow[b]{2}{*}{ Std. Error Mean } & \multicolumn{2}{|c|}{$\begin{array}{l}\text { 95\% Confidence Interval of the } \\
\text { Difference }\end{array}$} & & & \\
\hline & & & & & Lower & Upper & & & \\
\hline $\begin{array}{c}\text { Pair } \\
1\end{array}$ & $\begin{array}{c}\text { Pre-test - } \\
\text { post-test }\end{array}$ & -2.482 & 2.324 & .345 & -1.865 & -1.052 & -3.465 & 34 & .026 \\
\hline
\end{tabular}

The learners in experimental classe 2 and class 3 receiving type 1 and type 2 of corrective feedback respectively, the paired-samples $\mathrm{T}$ test (table 4.3) analysis revealed that there was significant difference as a result of the different treatment in long term study $(\mathrm{p}=0.026<0.05)$.that is to say, the effect of type 1 and type 2 on improving oral accuracy are different.

TABLE4.4

\begin{tabular}{|c|c|c|}
\hline & E2 & E3 \\
\hline $\mathrm{N} \quad$ Valid & 4 & 4 \\
\hline Missing & 0 & 0 \\
\hline Mean & 0.046 & 0.053 \\
\hline Std. Deviation & 2.516611 & 7.325754 \\
\hline
\end{tabular}

The descriptive statistics for two experimental classes, including class mean and standard deviations in post-test demonstrated that experimental class 2 was better than class 3 , because the ratio of error in class 2 is lower than class 3. In other words, type1 has better effect on improving oral accuracy the type2.

Lyster and Ranta (1997) presented a study of classroom interaction and classified various types of corrective feedback used by teachers in response to learner errors. The results shown that most teachers like recast, But recasts led to the lowest rate of uptake-including the lowest rate of repair. What is more, both recasts and explicit correction can 
not lead to any peer-or self-repair in that they already provide correct forms to learners. Opposite to that, elicitation, metalinguistic clues, clarification request, and the repetition of error not only made higher rates of uptake but also can be able to elicit peer- and self-repair. The last four techniques are called negotiation of form. The negotiation of form can benefit second language learner in at least two ways: (1) by providing opportunities for learners to proceduralize target language knowledge already internalized in declarative form (cf. Hulstijn, 1990;Mclaughlin, 1990; Nobuyoshi \& Ellis, 1993; Towell, Awkins \& Bazergui,1996) and (b) by drawing learners' attention to form during communicative interaction in ways that allowed them to re-analyze and modify their non-target output as they tested new hypotheses about the target language (Pica, 1988; Swain, 1993,1995).

TABLE 4.5

PAIRED-SAMPLES T TEST FOR LEARNERS IN THREE HIGH GROUPS

\begin{tabular}{|c|c|c|c|c|c|c|c|c|c|}
\hline & & \multicolumn{5}{|c|}{ Paired Differences } & \multirow[b]{3}{*}{$\mathrm{t}$} & \multirow[b]{3}{*}{ df } & \multirow[b]{3}{*}{ Sig. (2-tailed) } \\
\hline & & \multirow[b]{2}{*}{ Mean } & \multirow[b]{2}{*}{ Std. Deviation } & \multirow{2}{*}{$\begin{array}{l}\text { Std. Error } \\
\text { Mean }\end{array}$} & \multicolumn{2}{|c|}{$\begin{array}{l}\text { 95\% Confidence Interval of the } \\
\text { Difference }\end{array}$} & & & \\
\hline & & & & & Lower & Upper & & & \\
\hline Pair 1 & $\begin{array}{c}\text { Pre-test - } \\
\text { post-test }\end{array}$ & 1.750000 & 3.862210 & 1.931105 & -4.395638 & 7.895638 & .906 & 3 & .432 \\
\hline
\end{tabular}

From table 4.5 can revealed that learners in high group made little progress after a long time study. May be because learners in high group have mastered grammatical rules greatly and their oral speaking has been very accurately. What they do in the future is to speak more and improve there oral fluency and complexity. Teacher should pay more attention to learners in medium and low group.

\section{CONCLUSION}

The present study aims to investigate the effect of corrective feedback on oral accuracy. The foregoing discussion results in the following findings.

1. Corrective feedback has a positive effect on improving oral English accuracy. Compared with score of experimental classes and control class in post -test, the score of experimental class obvious is higher than that of control class.

2. Two types of corrective feedback, type1 have a better effect on English accuracy than type2.according to noticing theory, type 1 refers to corrective feedback can encourage learners self- correct errors; type 2 means corrective feedback that learners usually do not self-correct. According to noticing theory, in order to make input become intake for L2 learning, some degree of noticing must occur, type1 can make learners more noticed on correct form than that of type2.

3. Corrective feedback does make great effect on oral accuracy, but the effectiveness for different level of learner is different. For medium and low group learners, the effectiveness is better, because there is enough space for them to be improved. For high group learners, their oral accuracy is better, what they need to do is improve their oral fluency and complexity.

\section{REFERENCES}

[1] Bohannon, J. N., \& Stanowicz, L. (1988). The issue of negative evidence: Adult responses to children's language errors. Developmental Psychology, 24, 684-689.

[2] Day, Richard R., Chenoweth, N. Ann, Chun, Ann E., and Luppescu, Stuart. (1984). Corrective feedback in native-nonnative discourse. Language Learning, 34, 19-45.

[3] Demetras, M., Post, K., \& Snow, C. (1986). Feedback to first language learners: The role of repetitions and clarification requests. Journal of Child Language, 13, 275-292.

[4] Doughty, C., \& Varela, E. (1998). Communicative focus on form. In C. Doughty \& J. Williams (Eds.), Focus on form in classroom second language acquisition (pp. 114-138). Cambridge: Cambridge University Press.

[5] Ellis, Rod (1994). The Study of Second Language Acquisition. Oxford Oxfordshire: Oxford University Press.

[6] Ellis, R. (2002b). "Does form-focused instruction affect the acquisition of implicit knowledge?". Studies in Second Language Acquisition 24 (2): 223-236.

[7] Farrar, M. J. (1992). Negative evidence and grammatical morpheme acquisition. Developmental Psychology, 28, 90-98.

[8] Foster, P. Tohkyn, A. Wigglesworth, G. (2000) Measuring spoken language: A unit for all reasons. Applied Linguistics (03):37-41.

[9] Hulstijn, J. (1990). A comparison between the information-processing and the analysis/control approaches to language learning. Applied Linguistics, 11, 30-45.

[10] Lightbown, P. M. \& Spada. (1999). N. How language are learned. Oxford: Oxford University Press.

[11] Long, M., S. Inagaki \& L. Ortega. (1998). The Role of Implicit Negative Feedback in SLA: Models and Recasts in Japanese and Spanish. The Modern Language Journal 82:357-71.

[12] Lyster, R.; Ranta, L. (1997). "Corrective feedback and learner uptake: Negotiation of form in communicative classrooms". Studies in Second Language Acquisition 19: 37-66.

[13] Nobuyoshi, J. and Ellis, R. (1993). Focused communication tasks and second language Acquisition. ELT Journal 47, $203-210$. 
[14] Omaggio, Alice C. (1986). Teaching language in context: Proficiency-oriented instruction. Boston: Heinle and Heinle. 479pp.

[15] Pica, T. (1988). Interactive adjustments as an outcome of NS-NNS negotiated interaction. Language Learning 38, 45-73.

[16] Saxton, M. (1997). The contrast theory of negative input. Journal of Child Language, 24, 139-161.

[17] Skehan, P. (1996). A framework for the implementation of task-based instruction. Applied Linguistics. 17(1):38-62.

[18] Swain, M.(1995). Three functions or output in second SLA learning. In G. Cook \& B. Seidhofer (Eds.), Principle and Practice in Applied Linguistics (PP.125-144) .Oxford: Oxford University Press.

[19] Tornberg, Ulrika. (2005). Språkdidaktik. Malmö: Gleerups Utbildning AB.

[20] Towell, R., Hawkins, R., \& Bazergui, N. (1996). The development of fluency in advanced learners of French. Applied Linguistics, 17, 84-119.

[21] Wenzhong Zhang. (2002). The Development of L12 Oral Fluency in The EFL classroom Setting. Changsha: Hunan Education Publishing House.

[22] White, L. (1991). Adverb placement in second language acquisition: some effects of positive and negative evidence in the classroom. Second Language Research, 7, 133-161.

Ruili Chu was born in Shandong, China 1985. She received her M.A degree in linguistic from Binzhou College, China in 2009.

She is currently a postgraduate in the school of Foreign language college of Tianjin polytechnic university, Tianjin, china. Her research interests include applied linguistics and American literature. 